\title{
Differential depression of myocardial function and metabolism by lactate and $\mathrm{H}^{+}$
}

\author{
MICHELE SAMAJ A, ${ }^{1}$ SONIA ALLIBARDI, ${ }^{1}$ GIUSEPPINA MILANO, ${ }^{1}$ GABRIELLA NERI, ${ }^{1}$ \\ BRUNO GRASSI, ${ }^{2}$ L. BRUCE GLADDEN, ${ }^{3}$ AND MICHAEL C. HOGAN ${ }^{4}$ \\ 1Dipartimento di Scienze e Tecnologie Biomediche, University of Milan, I-20090 Milan, Italy; \\ 2Istituto di Tecnol ogie Biomediche Avanzate, CNR, I-20090 Milan, Italy; ${ }^{3}$ Department of Health \\ and Human Performance, Auburn University, Alabama 36849-5323; and "Department of Medicine, \\ University of California, San Diego 92093-0623
}

\begin{abstract}
Samaja, Michele, Sonia Allibardi, Giuseppina Milano, Gabriella Neri, Bruno Grassi, L. Bruce Gladden, and Michael C. Hogan. Differential depression of myocardial function and metabolism by lactate and $\mathrm{H}^{+}$. Am. J. Physiol. 276 (Heart Circ. Physiol . 45): H3-H8, 1999.-The effects of both high blood $\mathrm{H}^{+}$concentration $\left(\left[\mathrm{H}^{+}\right]\right)$and high blood lactate concentration ([lactate]) under ischemiareperfusion conditions are receiving attention, but little is known about their effects in nonischemic hearts. I solated rat hearts were Langendorff perfused at constant flow with media at two pH values (7.4 and 7.0) and two [lactate] ( 0 and $20 \mathrm{mM}$ ) in various sequences ( $\mathrm{n}=6$ /group). Coronary flow and arterial $\mathrm{O}_{2}$ content were kept constant at levels that allowed hearts to function without $\mathrm{O}_{2}$ supply limitation. We measured contractility, $\mathrm{O}_{2}$ uptake, diastolic pressure, and at the end of the protocol, tissue [lactate] and $\mathrm{pH}$. Perfusion with high [lactate] raised tissue [lactate] from $5.5 \pm 0.1$ to $17.5 \pm$ $2.6 \mu \mathrm{mol} /$ heart $(\mathrm{P}<0.0001)$, whereas decreasing the $\mathrm{pH}$ of the medium decreased tissue $\mathrm{pH}$ from $6.94 \pm 0.02$ to $6.81 \pm$ $0.06(P=0.002)$. Heart rate was not affected by high [lactate] but was reversibly depressed by high $\left[\mathrm{H}^{+}\right](\mathrm{P}=0.004)$. Developed pressure declined by $20 \%$ in response to high [lactate], high $\left[\mathrm{H}^{+}\right]$, and high [lactate] + high $\left[\mathrm{H}^{+}\right](\mathrm{P}=$ 0.002). After the high-[lactate] challenge was withdrawn, pressure continued to decline. In contrast, withdrawing the high $\left[\mathrm{H}^{+}\right]$challenge allowed partial recovery. The behavior of diastolic pressure mirrored that of developed pressure. Although unaffected by high [lactate], the $\mathrm{O}_{2}$ uptake was reversibly depressed by high $\left[\mathrm{H}^{+}\right]$. This suggests higher $\mathrm{O}_{2}$ cost per contraction in the presence of high [lactate]. We conclude that for similar acute contractility depression, high [lactate] induces irreversible damage, likely at some point in the pathway of $\mathrm{O}_{2}$ utilization. In contrast, the effect of high $\left[\mathrm{H}^{+}\right]$appears reversible. These differential behaviors may have implications for heart function during heavy exercise and ischemia-reperfusion events.
\end{abstract}

myocardial performance; isolated heart; $\mathrm{pH}$

DURING MYOCARDIAL ISCHEMIA, lactic acid accumulates in the cell cytosol as a consequence of the switch from aerobic to anaerobic metabolism. The subsequent $\mathrm{H}^{+}$ load activates several mechanisms that ultimately impair myocardial function $(1,16)$. One of these mechanisms is the inhibition of certain key enzymes of glycolysis by $\mathrm{H}^{+}$(18). Although this mechanism inhibits myocardial performance, it may turn out to be

\footnotetext{
The costs of publication of this article were defrayed in part by the payment of page charges. The article must therefore be hereby marked "advertisement" in accordance with 18 U.S.C. Section 1734 solely to indicate this fact.
}

protective during reperfusion of ischemic tissue, be cause it decreases tissue energy needs, thereby enhancing myocardial recovery $(11,19,21)$.

There are instances unrelated to ischemia, e.g., heavy exercise, when blood lactate concentration ([lactate]) may reach $20 \mathrm{mM}$ (10). This raises the issue of whether or not such a high [lactate] may become relevant for heart contractility even under normal perfusion conditions. A significant question is to what extent the possible effects are caused by the lactate anion versus $\mathrm{H}^{+}$. Hogan et al. (13) reported that high [lactate] and high blood $\mathrm{H}^{+}$concentration $\left(\left[\mathrm{H}^{+}\right]\right)$independently depress contractility in working dog muscle. Andrews et al. (3) showed a biphasic specific effect of $L(+)$-lactate (maximal at [lactate] $=25 \mathrm{mM}$ ) on $\mathrm{Ca}^{2+}$-activated force in cardiac papillary fibers independent of pH. Cairns et al. (5) found that exposure of myocytes to $20 \mathrm{mM}$ [lactate] exacerbates the intracellular $\mathrm{Ca}^{2+}$ load induced by acidosis. Studies in ischemic-reperfused, isolated hearts show that lactate, and not $\mathrm{H}^{+}$, contributes to the postischemic damage (8). Indeed, in that model, hearts did not recover at all from ischemia when perfused with $10 \mathrm{mM}$ [lactate]. Although this observation can be explained with increased lactate-to-pyruvate and hence $\mathrm{NADH}^{-t o-\mathrm{NAD}^{+}}$ratios, it appears important to assess whether high [lactate] and/or high $\left[\mathrm{H}^{+}\right]$may impair cardiac function independently of ischemia-reperfusion. The aim of this study was therefore to test the separate effects of elevated levels of high [lactate] and high $\left[\mathrm{H}^{+}\right]$in normally perfused hearts, thereby excluding the potentially confounding effects of ischemia.

\section{MATERIALS AND METHODS}

Apparatus. Rat hearts were Langendorff perfused with Krebs-Hensel eit media containing varying amounts of lactate and $\mathrm{H}^{+}$. Salts (Sigma Diagnostics, St. Louis, MO) were of the highest available purity, and care was taken to maintain near constant ionic strength (Table 1). The media were equilibrated in membrane oxygenators at $\mathrm{PO}_{2}=619 \pm 18 \mathrm{mmHg}$ (mean $\pm \mathrm{SE}$ ) and $\mathrm{PCO}_{2}=43 \pm 1 \mathrm{mmHg}$. A peristaltic pump (Gilson, Villiers LeBel, F rance) delivered the medium at fixed flow (15 $\mathrm{ml} / \mathrm{min}$ ) to an 8- $\mu \mathrm{m}$-pore size filter (Nucleopore, Pleasanton, CA), the preheater, and the aortic cannula. All the components of the perfusion system were kept at $37^{\circ} \mathrm{C}$ by an external water bath (Endocal, Neslab I nstruments, Newington, $\mathrm{NH}$ ).

Heart perfusion. Male Sprague-Dawley rats fed ad libitum (wt 250-280 g) were anesthetized with an intraperitoneal injection of heparinized thiopental sodium (10 mg/100 g body wt). Hearts (average wt $0.90 \pm 0.05 \mathrm{~g}$ ) were rapidly excised, 
Table 1. Composition of media

\begin{tabular}{|c|c|c|c|c|}
\hline & \multicolumn{2}{|c|}{ Nominal pH 7.4} & \multicolumn{2}{|c|}{ Nominal pH 7.0} \\
\hline & $0 \mathrm{mM}$ lactate & 20 mM lactate & $0 \mathrm{mM}$ lactate & $20 \mathrm{mM}$ lactate \\
\hline \multicolumn{5}{|c|}{ Salt, mM } \\
\hline $\begin{array}{l}\mathrm{NaCl} \\
\mathrm{KCl} \\
\mathrm{Na}_{2} \mathrm{SO}_{4} \\
\mathrm{Na}_{2}-\mathrm{EDTA} \\
\mathrm{MgCl}_{2} \\
\mathrm{CaCl}_{2} \\
\mathrm{KH}_{2} \mathrm{PO}_{4} \\
\mathrm{NaHCO}_{3} \\
\mathrm{GlucOse} \\
\mathrm{Na} \text {-lactate } \\
\mathrm{NaOH}\end{array}$ & $\begin{array}{r}116.0 \\
4.7 \\
1.2 \\
0.5 \\
1.2 \\
2.5 \\
1.2 \\
25.0 \\
11.0 \\
0.0 \\
1.0\end{array}$ & $\begin{array}{r}92.8 \\
4.7 \\
1.2 \\
0.5 \\
1.2 \\
2.5 \\
1.2 \\
25.0 \\
11.0 \\
20.0 \\
1.0\end{array}$ & $\begin{array}{r}129.9 \\
4.7 \\
1.2 \\
0.5 \\
1.2 \\
2.5 \\
1.2 \\
9.0 \\
11.0 \\
0.0 \\
1.0\end{array}$ & $\begin{array}{r}111.4 \\
4.7 \\
1.2 \\
0.5 \\
1.2 \\
2.5 \\
1.2 \\
9.0 \\
11.0 \\
20.0 \\
1.0\end{array}$ \\
\hline \multicolumn{5}{|c|}{ Ions, mM } \\
\hline $\begin{array}{l}\mathrm{Na}^{+} \\
\mathrm{K}^{+} \\
\mathrm{Ca}^{2+} \\
\mathrm{Cl}^{-}\end{array}$ & $\begin{array}{r}145.4 \\
5.9 \\
2.5 \\
123.1\end{array}$ & $\begin{array}{r}142.2 \\
5.9 \\
2.5 \\
99.9\end{array}$ & $\begin{array}{r}143.3 \\
5.9 \\
2.5 \\
137.0\end{array}$ & $\begin{array}{r}144.8 \\
5.9 \\
2.5 \\
118.5\end{array}$ \\
\hline \multicolumn{5}{|c|}{ Osmolarity, mosM } \\
\hline & 309.7 & 303.3 & 305.5 & 308.4 \\
\hline
\end{tabular}

immersed in isotonic saline solution $\left(20^{\circ} \mathrm{C}\right)$, and mounted on the system. A saline-filled latex balloon, introduced into the left ventricle, was connected to a pressure transducer (model 52-9966, Harvard Apparatus, Natick, MA) to measure enddiastolic pressure (EDP), left ventricular developed pressure (LVDP), maximal rate of contraction $\left(+\mathrm{dP} / \mathrm{dt}_{\max }\right)$ and relaxation ( $-\mathrm{dP} / \mathrm{dtmax})$, and heart rate (HR). Coronary perfusion pressure (CPP) was monitored by an additional transducer connected to the aortic cannula. Venous return was collected from the pulmonary artery to measure venous $\mathrm{PO}_{2}$ (model 5300 Oxy.gen Monitor, YSI, Yellow Springs, $\mathrm{OH}$ ) and hence $\mathrm{O}_{2}$ uptake $\left(\mathrm{VO}_{2}\right)$.

Protocols. Hearts were stabilized for $30 \mathrm{~min}$ with $\mathrm{pH} 7.4$, zero-lactate buffer (baseline). During this period, the balloon volume was adjusted to achieve EDP $\approx 10 \mathrm{mmHg}$ and was kept constant for the remainder of the experiment. After control measurements, the perfusing medium was changed in various sequences (Table 2 ). To determine tissue $\mathrm{pH}$ and tissue [lactate] at the end of the last period, some hearts were freeze-clamped with tongs previously cooled in liquid nitrogen and were stored at $-80^{\circ} \mathrm{C}$ until analysis.

Biochemical analyses. The heart was removed from liquid nitrogen, and a small sample ( $\sim 100 \mathrm{mg}$ ) was quickly cut from the lower left ventricle. The sample was weighed, frozen, and homogenized in a medium ( $10 \mu \mathrm{l} / \mathrm{mg}$ ) containing (in mM) 145 $\mathrm{KCl}, 10 \mathrm{NaCl}$, and 5 iodoacetic acid, pH 7.0 (7). The mixture was subjected to repeated grinding with a ground-glass rod in
Table 3. Values for arterial, venous, and tissuepH and tissuelactate concentration

\begin{tabular}{lccccc}
\hline \hline & \multicolumn{3}{c}{ Nominal Arterial pH } \\
\cline { 2 - 3 } \cline { 5 - 6 } & \multicolumn{2}{c}{7.4} & & \multicolumn{2}{c}{7.0} \\
\cline { 2 - 3 } & $\begin{array}{c}0 \mathrm{mM} \\
\text { arterial } \\
\text { [lactate] }\end{array}$ & $\begin{array}{c}20 \mathrm{mM} \\
\text { arterial } \\
\text { [lactate] }\end{array}$ & & $\begin{array}{c}0 \mathrm{mM} \\
\text { arterial } \\
\text { [lactate] }\end{array}$ & $\begin{array}{c}20 \mathrm{mM} \\
\text { arterial } \\
\text { [lactate] }\end{array}$ \\
\hline Arterial pH & $7.34 \pm 0.01$ & $7.34 \pm 0.01$ & $6.98 \pm 0.01$ & $6.98 \pm 0.01$ \\
Venous pH & $7.24 \pm 0.01$ & $7.24 \pm 0.01$ & $6.90 \pm 0.01$ & $6.90 \pm 0.01$ \\
Tissue pH & $6.97 \pm 0.02$ & $6.91 \pm 0.02$ & & NA & $6.81 \pm 0.03$ \\
Tissuelactate, $\mathrm{mM}$ & $5.5 \pm 0.1$ & $16.8 \pm 1.4$ & & NA & $19.1 \pm 1.0$ \\
\hline
\end{tabular}

Values are means $\pm \mathrm{SE} ; \mathrm{n}=4-6$ hearts/group. [lactate], Lactate concentration; NA, not applicable.

ice water. For tissue $\mathrm{pH}$ analysis, an aliquot of the homogenized sample was immediately analyzed using a blood gas-pH analyzer (Ciba Corning M238, Milan, Italy) (7). The remainder was used for tissue lactate analysis by enzymatic methods (ESAT 6661, E ppendorf, Hamburg, Germany).

Statistics. Data are expressed as means \pm SE. To detect significant differences, we used the two-tailed Student's t-test for paired and unpaired observations as appropriate. The level of significance was set at $\mathrm{P}<0.05$.

\section{RESULTS}

The $\mathrm{pH}$ measured in the arterial inflow and in the venous effluent, as well as tissue $\mathrm{pH}$ and tissue [lactate], are reported in Table 3. Table 4 reports myocardial performance during control perfusion. Figure 1 shows the performance before, during, and after a lactate (group 3) or $\mathrm{H}^{+}$challenge (groups 1 and 2 combined) for periods 1-3 of Table 2. The significance of the effects of high [lactate] and high $\left[\mathrm{H}^{+}\right]$is tested against the first control condition, unless otherwise stated. Some parameters were not in a steady state at the end of the 10-min $\mathrm{H}^{+}$or lactate challenge, so final values were used to indicate effects.

LVDP declined to 81 and $80 \%$ of control for thelactate and $\mathrm{H}^{+}$challenges, respectively ( $\mathrm{P}=0.002$ for both). On return to control conditions, $\mathrm{H}^{+}$-challenged hearts partially recovered LVDP $(P=0.02$ vs. control $)$, whereas LVDP continued to decline steadily $(P=0.005$ vs. control, Fig. 1A) in lactate-challenged hearts. The responses of $+\mathrm{dP} / \mathrm{dt}_{\max }$ and $-\mathrm{dP} / \mathrm{dt}_{\max }$ (not shown) are superimposable on those shown for LVDP.

$\mathrm{HR}$ was depressed by high $\left[\mathrm{H}^{+}\right](\mathrm{P}=0.004$ vs. control) but not by high [lactate] $[\mathrm{P}=$ not significant (NS) vs. control, Fig. 1B]. On return to control condi-

Table 2. Sequence of perfusing media

\begin{tabular}{|c|c|c|c|c|c|c|}
\hline Group & $n$ & \multicolumn{5}{|c|}{ Period } \\
\hline 1 & & Control & $\uparrow \mathrm{H}^{+}$ & Control & $\uparrow$ Lactate & $\uparrow$ Lactate $+\uparrow \mathrm{H}^{+}$ \\
\hline \multirow[t]{2}{*}{2} & 6 & 0/7.4 & $0 / 7.0$ & $0 / 7.4$ & $20 / 7.0$ & $20 / 7.0$ \\
\hline & & Control & $\uparrow \mathrm{H}^{+}$ & Control & $\uparrow$ Lactate $+\uparrow \mathrm{H}^{+}$ & $\uparrow$ Lactate \\
\hline 3 & 5 & $0 / 7.4$ & $20 / 7.4$ & 0/7.4 & & \\
\hline
\end{tabular}

Numbers separated by slash refer to lactate concentration ([lactate], in mM) followed by arterial perfusate pH. 
Table 4. Performanceand metabolism during control perfusion

\begin{tabular}{lc}
\hline \hline Devel oped pressure, $\mathrm{mmHg}$ & $130.7 \pm 6.9$ \\
$+\mathrm{dP} / \mathrm{dt}_{\max }, \mathrm{mmH} \mathrm{g} / \mathrm{s}$ & $3,772 \pm 231$ \\
$-\mathrm{dP} / \mathrm{dt}_{\max }, \mathrm{mmH}^{\mathrm{g}} / \mathrm{s}$ & $1,868 \pm 94$ \\
$\mathrm{H}$ eart rate, $\mathrm{min}^{-1}$ & $261 \pm 4$ \\
Developed pressure $\cdot$ heart rate, $\mathrm{mmHg} \cdot \mathrm{min}^{-1} \cdot 10^{-3}$ & $34.03 \pm 1.87$ \\
Diastolic pressure, $\mathrm{mmHg}$ & $13.6 \pm 0.8$ \\
Perfusion pressure, $\mathrm{mmHg}$ & $85 \pm 6$ \\
Venous $\mathrm{PO}_{2}, \mathrm{mmHg}$ & $228 \pm 15$ \\
$\mathrm{O}_{2}$ uptake, $\mu \mathrm{mol} / \mathrm{min}$ & $9.29 \pm 0.31$ \\
Venous $\mathrm{pH}$ & $7.22 \pm 0.01$ \\
Venous $\mathrm{PCO}_{2}, \mathrm{mmHg}$ & $58 \pm 1$ \\
\hline
\end{tabular}

Values are means $\pm \mathrm{SE} ; \mathrm{n}=16$ hearts. Conditions of control perfusion: 0 lactate; $\mathrm{PO}_{2}=619 \pm 18 \mathrm{mmHg} ; \mathrm{PCO}_{2}=43 \pm 1 \mathrm{mmHg}$ $\mathrm{pH}=7.34 \pm 0.01 .+\mathrm{dP}^{2} \mathrm{dt}_{\max }$, maximal rate of contraction; $-\mathrm{dP} / \mathrm{dt}_{\max }$, maximal rate of relaxation.

tions, HR was the same as in controls for both groups $(P=N S)$.

LVDP.HR, an index of heart energy expenditure, declined to 70 and $75 \%$ of control for the lactate and $\mathrm{H}^{+}$ challenges, respectively ( $\mathrm{P}=0.001$ for both). On return to control conditions, $\mathrm{H}^{+}$-challenged hearts partially recovered LVDP.HR ( $P=0.03$ vs. control), whereas LVDP.HR continued to decline steadily in lactatechall lenged hearts ( $P=0.002$ vs. control, Fig. 1C).

$\mathrm{VO}_{2}$ was not affected by high [lactate] (Fig. ID, P = $\mathrm{NS})$ but was decreased by high $\left[\mathrm{H}^{+}\right](\mathrm{P}<0.0001)$. On return to control conditions, $\mathrm{VO}_{2}$ fell in lactatechallenged hearts ( $\mathrm{P}=0.03 \mathrm{vs}$. control), as opposed to complete recovery in $\mathrm{H}^{+}$-challenged hearts $(\mathrm{P}=\mathrm{NS}$ vs. control).

The effects of high $\left[\mathrm{H}^{+}\right]$and high [lactate] were comparable for both EDP ( $\mathrm{P}=0.05$, Fig. $1 \mathrm{E})$ and CPP $(P=0.003$, Fig. $1 F)$. On return to control conditions, $\mathrm{H}^{+}$-challenged hearts maintained diastolic contracture and vascular resistance, but these parameters were more compromised in lactate-challenged hearts ( $\mathrm{P}=$ 0.05 between groups).
To gain further insight into possible mechanisms of action, we exposed hearts that had recovered from the $\mathrm{H}^{+}$challenge to high [lactate], with and without high $\left[\mathrm{H}^{+}\right]$in alternate sequences (periods 4 and 5 of Table 2 ). The performance of lactate-challenged hearts was too unstable to allow further use. Data in Fig. 2 are expressed as a percentage of the value measured after recovery from high $\left[\mathrm{H}^{+}\right]$(period 3 in Table 2); therefore, each heart served as its own control. Increase of [lactate] or [lactate] $+\left[\mathrm{H}^{+}\right]$depressed LVDP by 19 and $21 \%$, respectively, as in Fig. $1 \mathrm{~A}$. Combining high $\left[\mathrm{H}^{+}\right]$ and high [lactate] caused further depression of LVDP, but removing the excess $\mathrm{H}^{+}$from the lactate- $\mathrm{H}^{+}$challenge caused no further deterioration of contractility. High [lactate] alone did not depress $H R$, as already shown in Fig. 1B, but high [lactate] + high $\left[\mathrm{H}^{+}\right]$ significantly $(P<0.0001)$ depressed HR (Fig. 2B). Finally, $\mathrm{VO}_{2}$ appeared to be unaffected by high [lactate] alone, but.high [lactate] + high $\left[\mathrm{H}^{+}\right]$significantly depressed $\mathrm{VO}_{2}$.

\section{DISCUSSION}

General considerations and comparison to in vivo si tuation. In this study, we addressed the separateroles of lactate and $\mathrm{H}^{+}$on myocardial function. We found that both high [lactate] and high $\left[\mathrm{H}^{+}\right.$] depress myocardial function independently of each other. However, for similar acute depressions of contractility, high [lactate] induces irreversible damage. In contrast, the effect of high $\left[\mathrm{H}^{+}\right]$appears reversible. Because these observations relate to isovolumic, denervated hearts perfused at constant flow with blood-free media, interference by nervous or humoral factors or by different loading conditions is ruled out.

In humans, systemic [lactate] can transiently reach $>20 \mathrm{mM}$ values during heavy exercise (10) without detrimental effects on cardiac function. I ndeed, myocardial contractility is often increased during exercise.
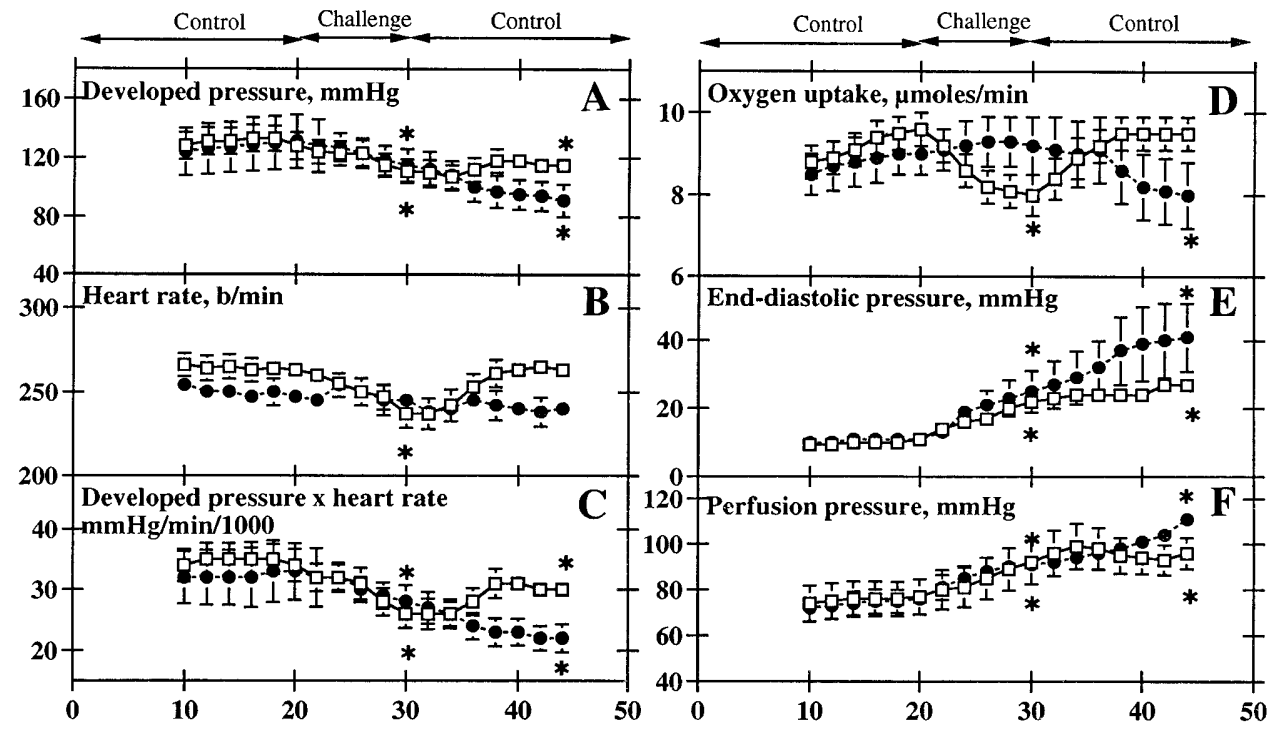

Fig. 1. Time course of changes (from top to bottom, left to right) in devel oped pressure (A), heart rate (B), devel oped pressure [multi] heart rate $(C)$, oxygen uptake (D), end-diastolic pressure (E), and perfusion pressure $(F)$ during periods $1-3$ of Table $2 . \mathrm{H}^{+}(\mathrm{n}=11$ hearts, $\square$ ) and lactate ( $\mathrm{n}=5$ hearts, $\bullet$ ) challenges were given from $t=20 \mathrm{~min}$ through $\mathrm{t}=30 \mathrm{~min}$. Statistical tests performed at end of various periods: $* P<0.05$ vs. baseline control perfusion.

Time, min 


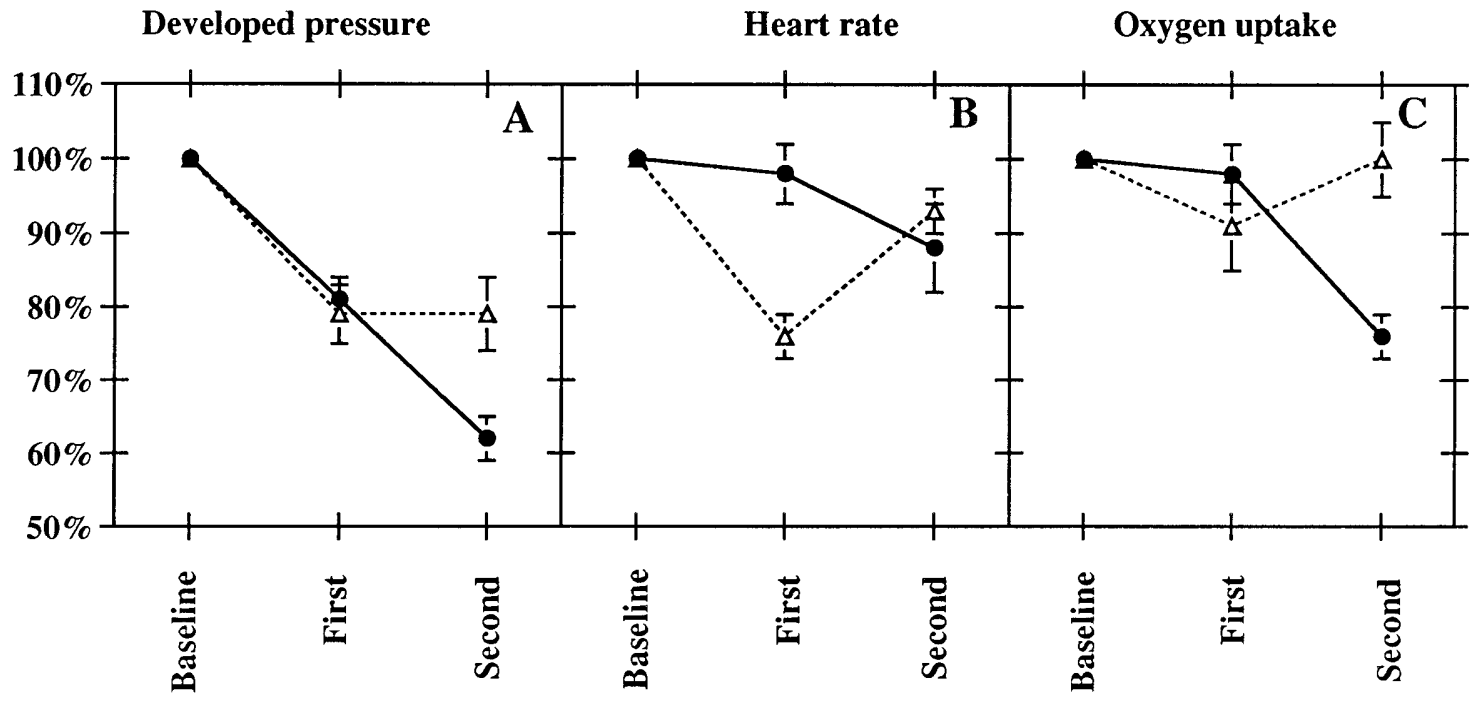

Fig. 2. Behavior of hearts recovered from $\mathrm{H}^{+}$challenge when exposed to high [lactate] alone and high [lactate] + high $\left[\mathrm{H}^{+}\right](\mathrm{n}=5$ hearts, $\bullet)$ or high [lactate] + high $\left[\mathrm{H}^{+}\right]$and high [lactate] alone $(\mathrm{n}=6$ hearts, $\triangle)$. Data are expressed as percentage of value at end of recovery from $\mathrm{H}^{+}$challenge.

However, exercise is a multifactorial environment, and heart contractility is the overall result of the interaction of many changing variables, e.g., increased blood $\mathrm{K}^{+}, \mathrm{Ca}^{2+}$, and catecholamines $(15,17)$. Therefore, it is not surprising that the separate effects of high $\left[\mathrm{H}^{+}\right]$and high [lactate] observed in this study, ruling out interference from other factors known to influence contractility, do not follow the in vivo trends. For example, in vivo changes in plasma $\mathrm{Ca}^{2+}$ have already been shown to effectively protect hearts from lactic acidosis (15). Accordingly, other factors must be important in offsetting the detrimental effects of high [lactate] and/or high $\left[\mathrm{H}^{+}\right]$. Additional studies are required to tease apart the separate and interactive effects of the various components that ultimately determine cardiac performance during exercise.

Critique of experimental model. Care was taken to minimize ion composition and strength changes when varying [lactate] and $\left[\mathrm{H}^{+}\right.$]. Constant coronary flow and arterial $\mathrm{PO}_{2}$ imply unaltered $\mathrm{O}_{2}$ supply, which was calculated to be $14.1 \mu \mathrm{mol} / \mathrm{min}$ throughout. This value is slightly higher than the $\mathrm{O}_{2}$ supply of in vivo hearts (8.5- $10.1 \mu \mathrm{mol} / \mathrm{min}$, when assuming coronary flow = $70-85 \mathrm{ml} \cdot 100 \mathrm{~g}^{-1} \cdot \mathrm{min}^{-1},[\mathrm{Hb}]=15.5 \mathrm{~g} / \mathrm{dl}$, and $98 \% \mathrm{O}_{2}$ saturated at arterial $\mathrm{PO}_{2}=100 \mathrm{mmH}$; Ref. 4). Therefore, factors linked to inadequate convective $\mathrm{O}_{2}$ delivery are minimized or eliminated.

The homogenate technique is an accurate and practical method for the estimation of intracellular $\mathrm{pH}$ (7) because measurements of tissue $\mathrm{pH}$ by biochemical and ${ }^{31} \mathrm{P}$ magnetic resonancespectroscopy methods arehighly correlated (20). The values for venous and tissue $\mathrm{pH}$ closely reflect the changes in $\left[\mathrm{H}^{+}\right]$in the perfusing medium. Decreasing arterial $\mathrm{pH}$ from 7.34 to 6.98 corresponds to an increase in $\left[\mathrm{H}^{+}\right]$of $59 \mathrm{nM}$. This increase in arterial $\left[\mathrm{H}^{+}\right]$causes a tissue $\left[\mathrm{H}^{+}\right]$increase by $41 \mathrm{nM}$, equivalent to a tissue $\mathrm{pH}$ decrease from 6.94 (average of all measurements with arterial $\mathrm{pH}=7.34$ ) to 6.81 (tissue $\mathrm{pH}$ for arterial $\mathrm{pH}=7.34$ ).
Tissue [lactate] also reflects the changes of [lactate] in the perfusing medium. Perfusing hearts with $20 \mathrm{mM}$ [lactate] induces a threefold rise of tissue [lactate]. Tissue [lactate] is an integrated index of both endogenous lactate production and exogenous lactate addition. F urthermore, it represents theaverage of intracellular and interstitial [lactate]. Therefore, these data certainly do not provide any quantitative information regarding lactate uptake.

Ex vivo myocardial responses to high [lactate] and high $\left[\mathrm{H}^{+}\right]$. Because the heart is not a homogeneous tissue, it is not surprising that the same lactate or $\mathrm{H}^{+}$ loads cause different responses in the various tissues that constitute the myocardial mass. Although a certain degree of interaction among the various tissues is expected in ex vivo models, some features of the model used here allow a discussion of the effects of lactate or $\mathrm{H}^{+}$in the various tissues.

The conducting system, the performance of which is best marked by $\mathrm{HR}$ changes, is influenced by $\mathrm{H}^{+}$but not by lactate. This finding is in agreement with thestudies by Karmazyn (14) and Cross et al. (8). In the present study, an $\mathrm{H}^{+}$load induces reversible HR depression, both in the absence (Fig. 1) and in the presence (Fig. 2) of a lactate load.

Because the volume of the intraventricular balloon is fixed at thestart of the perfusion, EDP raises proportionally to diastolic contracture. This stems from impaired $\mathrm{Ca}^{2+}$ sequestration into the sarcoplasmic reticulum secondary to low available ATP (2). EDP is influenced by lactate and $\mathrm{H}^{+}$in similar amounts. When $\left[\mathrm{H}^{+}\right]$is restored to normal in the medium, EDP stabilizes, as opposed to steadily increasing when lactate is removed from the medium. The finding that high [lactate] may induce irreversible damage to the $\mathrm{Ca}^{2+}$-sequestration system is consistent with the hypothesis that glycolytic ATP is crucial to maintain $\mathrm{Ca}^{2+}$ homeostasis (23) and thus that lactate-induced inhibition of glycolysis impairs the $\mathrm{Ca}^{2+}$-pumping mechanisms. Our finding is 
supported by the observation that cardiac myocytes exposed to $20 \mathrm{mM}$ lactate went into severe contracture (5).

In this model with constant coronary flow, the changes in vascular resistance are best characterized by changes in CPP. Like EDP, CPP is influenced by lactate and $\mathrm{H}^{+}$ in similar amounts. Likewise, when normal $\left[\mathrm{H}^{+}\right]$is restored CPP stabilizes, as opposed to steadily increasing when lactate is removed from the medium. Although this might suggest irreversible damage infer red to the endothelium by lactate, the increased vascular resistance may be secondary to myocardial stiffness originated by diastolic contracture (22).

A major constituent of the myocardium, the contractile system, is best assessed by both LVDP and LVDP.HR in this model. The contractile system is also the major determinant of $\mathrm{V}_{2}$. Both high [lactate] and low $\mathrm{pH}$ reduce contractility in hearts perfused under saturating conditions, but a load of $20 \mathrm{mM}$ [lactate] is required to cause the same decline of contractility caused by $59 \mathrm{nM} \mathrm{H}^{+}$. On return to control conditions, lactate-challenged hearts exhibit steady decline of both LVDP and LVDP $\cdot H R$, as opposed to partial recovery in $\mathrm{H}^{+}$-challenged hearts. The lactate challenge therefore induces irreversible injury, in contrast with the partially reversible injury induced by high $\left[\mathrm{H}^{+}\right]$. The former finding is in contrast with the reversible effect of high [lactate] on isolated cardiac papillary fibers (3), but in those experiments the time duration of exposure to high [lactate] was $<20 \mathrm{~s}$ at $22^{\circ} \mathrm{C}$. Figure $2 \mathrm{~A}$ shows that LVDP stabilizes after the $\mathrm{H}^{+}$challenge is removed from the combined high [lactate] + high $\left[\mathrm{H}^{+}\right]$challenge. The fact that LVDP does not continue to decline may be caused by offsetting effects of lactate decreasing ventricular function and improving ventricular function because of the removal of the $\mathrm{H}^{+}$challenge. As the depressions caused by high [lactate] and high [lactate] + high $\left[\mathrm{H}^{+}\right]$are similar (compare Fig. 1A with Fig. 2A), it appears that the effects of the two challenges are not additive.

The separate effects of high $\left[\mathrm{H}^{+}\right]$and high [lactate] in normally perfused hearts has not been the subject of extensive investigation. Drake-Holland et al. (9) first showed that $4.6 \mathrm{mM}$ lactate does not affect $\mathrm{O}_{2}$ consumption in the presence of palmitateand glucose. Karmazyn (14) showed that $20 \mathrm{mM}$ [lactate] depresses force devel opment by $24 \%$. Cross et al. (8) reported a nonsignificant depression of LVDP by $21 \%$ in the presence of $10 \mathrm{mM}$ [lactate]. Hogan et al. (13) reported, in a model of in situ dog muscle perfused with [lactate] $10 \mathrm{mM}$ higher than baseline, a decrease of developed tension by $15 \%$. A key finding in the present study is that, in $\mathrm{H}^{+}$-challenged hearts, the $30 \%$ decljne of LVDP $\cdot \mathrm{HR}$ is accompanied by a $15 \%$ dedine of $\mathrm{VO}_{2}$. In contrast, in lactate-challenged hearts, the $25 \%$ decline of LVDP $\cdot H R$ occurs at constant $\mathrm{VO}_{2}$. Thus, in the presence of compromised function caused by high [lactate], significantly more $\mathrm{O}_{2}$ is consumed per unit contractility (higher $\mathrm{VO}_{2}$-to-LVDP $\cdot \mathrm{HR}$ ratio).

The latter observation is puzzling, because it is not likely that the extra $\mathrm{VO}_{2}$ is directed to synthesize more
ATP. The observed feature can thus be explained either with decreased bioenergetic efficiency or with increased ATP consumption in paths not linked to contraction. The first hypothesis might involve impaired phosphorylative coupling efficiency, possibly because high cell [lactate] dissipates the $\mathrm{H}^{+}$gradient created by the electron transport chain via the lactate- $\mathrm{H}^{+}$cotransport protein on the inner mitochondrial membrane (12). However, such an effect would only be transient because once mitochondrial lactate equilibrates with cytosolic lactate, there would be no further impact. Alternatively, high cell [lactate] might have decreased the contraction coupling efficiency, but direct effects of lactate (up to $50 \mathrm{mM}$ ) on steady-state isometric force of contraction in rabbit fast and slow skeletal muscle fibers were excluded (6). As for the second hypothesis, exposure of ventricular myocytes to $20 \mathrm{mM}$ lactate was shown to increase the amplitude of $\mathrm{Ca}^{2+}$ transients by $18 \%$ (5). The subsequent increased $\mathrm{Ca}^{2+}$ load would have increased the $\mathrm{O}_{2}$ cost to pump out $\mathrm{Ca}^{2+}$. Alternatively, the higher $\mathrm{O}_{2}$ cost of contraction might be secondary either to a high NADH-to-NAD ${ }^{+}$ratio that inhibits glycolysis (8) or to the inhibition of $\mathrm{Na}^{+} / \mathrm{H}^{+}$ exchange (14), which increases the intracellular $\mathrm{Ca}^{2+}$ load and hence the cost to pump out $\mathrm{Ca}^{2+}$. As a matter of fact, our study is certainly not conclusive and is being followed by additional ones that examine in detail the various hypotheses.

In conclusion, both $\mathrm{H}^{+}$and the lactate anion depress myocardial contractility even in non- $\mathrm{O}_{2}$-limited hearts, but our results show that different mechanisms are involved. For example, the various myocardial functions respond differently to the same lactate or $\mathrm{H}^{+}$ loads. In principle, the effect of $\mathrm{H}^{+}$can be attributed to an allosteric-like inhibition of key enzymes. However, high [lactate] irreversibly impairs contractility, perhaps because the lactate-associated $\mathrm{Ca}^{2+}$ overload limits the mitochondrial function.

This research was supported by NATO Grant 950173.

Address for reprint requests: M. Samaja, Dipartimento di Scienze e Tecnol ogie Biomediche, via Cervi 93, I-20090 Segrate Milan, Italy.

Received 30 March 1998; accepted in final form 2 September 1998.

\section{REFERENCES}

1. Allard, M. F., P. G. Emanuel, J . A. Russell, S. P. Bishop, S. B. Digerness, and P. G. Anderson. Preischemic glycogen reduction or glycolytic inhibition improves postischemic recovery of hypertrophied rat hearts. Am. J . Physiol. 267 (Heart Circ. Physiol. 36): H66-H74, 1994.

2. Allen, D. G., and C. H. Orchard. Myocardial contractile function during ischemia and hypoxia. Circ. Res. 60: 153-168, 1987.

3. Andrews, M. A. W., R. E. Godt, and T. M. Nosek. Influence of physiological $\mathrm{L}(+)$-lactate concentrations on contractility of skinned striated muscle fibers of rabbit. J. Appl. Physiol. 80: 2060-2065, 1996.

4. Braunwald, E. Control of myocardial oxygen consumption. Physiologic and clinical considerations. Am. J. Cardiol. 27: 416-432, 1971.

5. Cairns, S. P., H. Westerblad, and D. G. Allen. Changes in myoplasmic $\mathrm{pH}$ and calcium concentration during exposure to lactate in isolated rat ventricular myocytes. J. Physiol. (Lond.) 464: 561-574, 1993. 
6. Chase, P. B., and M. J. Kushmerick. Effects of $\mathrm{pH}$ on contraction of rabbit fast and slow skeletal muscle fibers. Biophys. J . 53: 935-946, 1988.

7. Costill, D. L., R. L. Sharp, W.J . Fink, and A. Katz. Determination of human muscle pH in needle-biopsy specimens. J. Appl. Physiol. 53: 1310-1313, 1982.

8. Cross, H. R., K. Clarke, L. H. Opie, and G. K. Radda. Is lactate-induced myocardial ischemic injury mediated by de creased $\mathrm{pH}$ or by increased intracellular lactate? J. Mol. Cell. Cardiol. 27: 1369-1381, 1995.

9. Drake-Holland, A. J ., G. Elzinga, M. I. Noble, H. E. ter Keurs, and F. N. Wempe. The effect of palmitate and lactate on mechanical performance and metabolism of cat and rat myocardium. J . Physiol. (Lond.) 339: 1-15, 1983.

10. Gladden, L. B. Lactate transport and exchange during exercise. In: Handbook of Physiology. Exercise: Regulation and Integration of MultipleSystems. Bethesda, MD: Am. Physiol. Soc., 1996, sect. 12 , chapt. 14, p. 614-648.

11. Goodwin, G. W., and H. Taegtmeyer. Metabolic recovery of isolated working rat heart after brief global ischemia. Am. J. Physiol. 267 (Heart Circ. Physiol. 36): H462-H470, 1994

12. Halestrap, A. P., and A. E. Armston. A re-evaluation of the role of mitochondrial pyruvate transport in the hormonal control of rat liver mitochondrial pyruvate metabolism. Biochem. J . 223: 677-685, 1984

13. Hogan, J ., L. B. Gladden, S. S. Kurdak, and D. C. Poole Increased lactate in working dog muscle reduces tension development independent of pH. Med. Sci. Sports Exerc. 27: 371-377, 1995.

14. Karmazyn, $\mathbf{M} . \mathrm{Na}^{+} / \mathrm{H}^{+}$exchange inhibitors reverse lactateinduced depression in postischemic ventricular recovery. Br. J . Pharmacol. 108: 50-56, 1993.
15. Leitch, S. P., and D. J . Paterson. Role of calcium in protecting the heart from hyperkalemia and acidosis in the rabbit: implications for exercise. J . Appl. Physiol. 77: 2391-2399, 1994.

16. Neely, J . R., and L. W. Grotyohann. Role of glycolytic products in damage to ischemic myocardium. Circ. Res. 55: 816- 824, 1984.

17. Paterson, D. J . Antiarrhythmic mechanisms during exercise. J Appl. Physiol. 80: 1853-1862, 1996.

18. Rovetto, M. J ., W. F. Lamberton, and J . R. Neely. Mechanisms of glycolytic inhibition in ischemic rat hearts. Circ. Res. 37: 742-751, 1975

19. Samaja, M., R. Motterlini, S. Allibardi, S. Casalini, G. Merati, A. Corno, and S. Chierchia. Myocardial metabolism and function in acutely ischemic and hypoxemic isolated rat hearts. J . Mol. Cell. Cardiol. 27: 1213-1218, 1995.

20. Sullivan, M. J ., B. Saltin, R. Negro-Vilar, B. D. Duscha, and H. C. Charles. Skeletal muscle pH assessed by biochemical and 31P-MRS methods during exercise and recovery in men. J . Appl. Physiol. 77: 2194-2200, 1994.

21. Vanoverschelde, J .-L. J ., M. F. J anier, J . E. Bakke, D. R. Marshall, and S. R. Bergmann. Rate of glycolysis during ischemia determines extent of ischemic injury and functional recovery after reperfusion. Am. J. Physiol. 267 (Heart Circ. Physiol. 36): H1785-H1794, 1994.

22. Wexler, L. F., E. O. Weinberg, J. S. Ingwall, and C. S. Apstein. Acute alterations in diastolic left ventricular chamber distensibility: mechanistic differences between hypoxemia and ischemia in isolated perfused rabbit and rat hearts. Circ. Res. 59: 515-528, 1986

23. Xu, K. Y., J . L. Zweier, and L. C. Becker. Functional coupling between glycolysis and sarcoplasmic reticulum $\mathrm{Ca}^{2+}$ transport. Circ. Res. 77: 88-97, 1995.

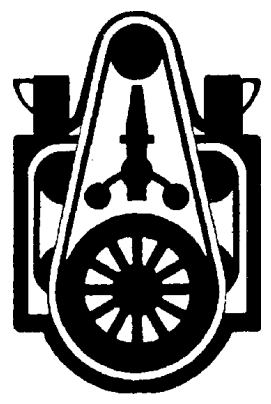

